\title{
Nem invazív fibrosisdiagnosztika hepatitis C-vírus-infekcióban: szerepe a kezelés indikációjában, követésében és a prognózis megítélésében
}

\author{
Pár Alajos dr. - Vincze Áron dr. - Pár Gabriella dr. \\ Pécsi Tudományegyetem, Klinikai Központ, Általános Orvostudományi Kar, I. Belgyógyászati Klinika, Pécs
}

\begin{abstract}
A krónikus hepatitis C-vírus-infekció okozta necroinflammatio májfibrosisra és cirrhosisra hajlamosít, ami a végstádiumú májbetegség szövődményeihez vezet. A fibrosisstádium ismerete alapvető fontosságú mind az antivirális terápia indikálásában és a kórlefolyás alatti követésben, mind a prognózis előrejelzésében. Mivel a fibrosisdiagnosztikában „aranystandarnak” tekintett májbiopszia invazív és ismétlésének is korlátai vannak, előtérbe kerültek a fibrosisstádium meghatározását szolgáló nem invazív módszerek. A szérumbiomarkerek és a fizikai megközelítésen (a májtömöttség vizsgálatán) alapuló elasztográfiás eljárások, valamint ezek kombinációs algoritmusai képviselik azokat az eljárásokat, amelyek egyre inkább beépülnek a kezelési irányelvekbe, és alkalmazásuk révén csökkenthető a májbiopszia igénye. A dolgozat áttekintést ad a fibrosisdiagnosztika nem invazív módszereiről, azok szerepéről az antivirális kezelés elkezdésében, a terápiás válasz monitorozásában és a prognózis megítélésében krónikus hepatitis C-vírus-infekcióban szenvedő betegekben. Orv. Hetil., 2015, 156(21), 855-861.
\end{abstract}

Kulcsszavak: hepatitis C-vírus, fibrosis, nem invazív eljárások, kezelés, követés, prognózis, szérumbiomarkerek, elasztográfia

\section{Non-invasive diagnostic methods of fibrosis \\ in chronic hepatitis $\mathrm{C}$ virus infection: their role in treatment indication, follow-up and assessment of prognosis}

\begin{abstract}
Chronic hepatitis C virus infection associated with necroinflammation predisposes to liver fibrosis and cirrhosis, which lead to severe end-stage complications. Staging of fibrosis is of basic importance for the indication of antiviral treatment, for monitoring the response and predicting the prognosis of patients with hepatitis $\mathrm{C}$ virus related liver disease. Since liver biopsy, the "gold standard” diagnosis of fibrosis is invasive and it has some other limitations, noninvasive methods have been developed and widely used in the clinical practice. Serum biomarkers and physical approaches measuring liver stiffness by elastography as well as combination algorithms have been gradually been integrated into guidelines resulting in a reduction of the need for liver biopsy. The authors review these non-invasive fibrosis markers and discuss their role in the indication of treatment, follow-up, and assessment of prognosis of patients with chronic hepatitis $\mathrm{C}$ virus infection.
\end{abstract}

Keywords: hepatitis C virus, fibrosis, non-invasive assessment, treatment, follow-up, prognosis, serum biomarkers, elastography

Pár, A., Vincze, Á., Pár, G. [Non-invasive diagnostic methods of fibrosis in chronic hepatitis C virus infection: their role in treatment indication, follow-up and assessment of prognosis]. Orv. Hetil., 2015, 156(21), 855-861.

(Beérkezett: 2015. március 21.; elfogadva: 2015. április 14.) 


\section{Rövidítések}

ALT = alanin-aminotranszferáz; AMA = antimitochondrialis antitest; APRI = alanin-aminotranszferáz/thrombocyta hányadosindex; ARFI = acoustic radiation force impulse; AST $=$ aszpartát-aminotranszferáz; $\mathrm{CSPH}=$ klinikailag szignifikáns portalis hypertensio; GOT = glutaminsav-oxálecetsav-tranzamináz; GPT = glutaminsav-piroszőlősav-tranzamináz; DAA = direkt ható antivirális szer; DAMP = danger-associated molecular patterns; GGT = gamma-glutamil-transzferáz; $\mathrm{HCC}=$ hepatocellularis carcinoma; $\mathrm{HCV}=$ hepatitis $\mathrm{C}$-vírus; $\mathrm{HSC}=$ hepaticus stellatumsejt; HVPG = hepaticus vénásnyomás-gradiens; $\mathrm{NPV}=$ negatív prediktív érték; LS = (liver stiffness) májtömöttség; LSPR = májtömöttség-lépátmérő/thrombocyta hányados; $\mathrm{P}=$ Paquet; peg-IFN = pegilált interferon; $\mathrm{PPV}=$ pozitív prediktív érték; $\mathrm{P} / \mathrm{R}=$ pegilált interferon plusz ribavirin; PSR = thrombocytaszám/lépátmérő hányados; SS = (spleen stiffness) léptömöttség; SVR = (sustained virological response) tartós virológiai válasz; $\mathrm{TE}=$ tranziens elasztográfia; TGF- $\beta$ = transzformáló növekedési faktor béta; TLR = toll-like receptor.

A világon jelenleg 170-185 millióra becsülik a hepatitis C-vírus- (HCV-) fertőzöttek számát [1, 2]. A HCV-infekció globális jelentősége ma egyre inkább előtérbe kerül, mivel a súlyos késői következményekkel járó HCVinfekció az esetek 75\%-ában nem diagnosztizált [3]. Az Amerikai Egyesült Államokban ez az arány 50\%, és eddig ott kevesebb mint a felismert esetek $20 \%$-át kezelték. Az is kiderült, hogy az 1945-1965 között születettek („baby boom”: az 50-70 év közöttiek) a népesség 27\%át jelentik, de ebben a populációban található a HCVfertőzöttek 75\%-a. Ezért az Amerikai Egyesült Államokban általános HCV-szürő programot hirdettek erre a korosztályra [4].

A HCV-szúrés költséghatékonysága elfogadott, lényeges, hogy ezt antivirális terápia kövesse, a HCV okozta morbiditás és mortalitás csak ily módon csökkenthetó [5]. Ebből a szempontból fontos a májbetegség kifejlődésében meghatározó fibrosis megelőzése, korai felismerése. A fibrosisstádium ismerete alapvetô, mint látni fogjuk, mind a terápia indikálásában, mind a prognózis tekintetében [6].

A HCV-infekció okozta fibrosis patogenezisében a kórokozó direkt és indirekt hatásaival kell számolni. HCV direkt fibrogenetikus hatását képviselik a stellatumsejteket (HSC) aktiváló NS3, NS4 enzimek, míg az E2 burokprotein proinflammatorikus utakon hat, gyulladásos választ indukál. A HCV-core oxidatív stresszt, toll-like receptor-2- (TLR-2-) és TGF-ß-aktivációt okoz. A HCV által kiváltott immunválasz indirekt úton indít fibrogenezist, a thrombocytákból (PDGF), a Kupffer-sejtekből és egyéb sejtekből származó citokinek (TGF- $\beta$, EGF, VEGF), kemokinek és az IL-6 révén [6].

A fibrogenezis az első lépés a HCV okozta krónikus májbetegség progressziójában. Fibrosis nélküli HCVfertőzöttek 25\%-ában fejlődik ki cirrhosis 20 év alatt, septalis fibrosis esetén ez már 10 év alatt kialakul [7].
A széles körben alkalmazható szúrővizsgálatok jelentősége a fibrosis korai felismerésének alapja, így egyre nagyobb hangsúlyt kapnak a fibrosis értékelésére szolgáló nem invazíp vizsgálóeljárások.

A májfibrosis nem invazív diagnosztikája már számos hazai közlemény tárgyát képezte $[8,9,10,11]$. Dolgozatunkban ez utóbb említettekre is hivatkozva, a fibrosisdiagnosztikával kapcsolatban elsősorban az antivirális terápia vonatkozásaival foglalkozunk. Nem térünk ki a májbiopszia tárgyalására, utalunk Schaff Zsuzsának az Orvosi Hetilapban megjelent dolgozatára [12].

A fibrosis fokának meghatározása krónikus HCVinfekcióban két szempontból jelentôs: egyrészt a METAVIR F $\geq 2$ stádium szignifikáns fibrosisra utal, ami lényeges az antivirális terápia indikációját tekintve, míg a METAVIR F4 stádium a cirrbosist jelzi, figyelmeztet a portalis hypertensio és a hepatocellularis carcinoma (HCC) irányában szükséges monitorozásra [6], egyben a prioritást jelentheti az IFN-mentes DAA-kezelésre [2].

A nem invazív fibrosisdiagnosztika a legutóbbi évtizedben fontos szerepet kapott az antivirális kezelés indikálásában, amióta a már említettek szerint egyre nyilvánvalóbb, hogy az eddigieknél szélesebb körben van szükség a HCV-szúrésre és az antivirális terápia kezdeményezésére. Ehhez pedig a HCV-RNS detektálásán (és a HCV-genotípus tisztázásán!) túl a fibrosisstádium ismerete is alapvető. A fibrosisdiagnosztikában „aranystandardnak" tartott májbiopszia populációs szưrővizizgálatokra nem alkalmas. A klinikumban a fibrosisdiagnózisra vonatkozó nem invazív vizsgálatok nem helyettesítik a biopsziát, de csökkentik a szükséges biopsziák számát $[6,13]$.

\section{Nem invazív módszerek a fibrosis értékelésében}

A fibrosisdiagnosztikában „biológiai” (szérumbiomarkerek) és „fizikai” megközelítésen (a májtömöttség mérésén) alapuló eljárások képviselik a nem invazív módszereket, ezek egymást kiegészítik. Amíg a májtömöttség mérése a parenchyma intrinszik fizikai sajátosságát tükrözi, a szérumbiomarkerek - nem feltétlen májspecifikus - vérkémiai mutatókon alapulnak, amelyek kapcsolatban lehetnek a fibrosisstádiummal.

\section{Szérumbiomarkerek}

Az úgynevezett direkt mutatók a májban az extracelluláris mátrix (ECM) lerakódását és eltávolítását tükrözik. Közöttük a legismertebbek a glikoproteinek (hialuronsav, laminin és YKl-40), kollagének (prokollagén-III peptid és IV. típusú kollagén), valamint a kollagenázok és inhibitoraik (mátrixmetalloproteáz, MMP-3 és a metalloproteáz-1 szöveti inhibitora, TIMP-1).

$\mathrm{Az}$ indirekt markerek rutinpróbák, mint a protrombinindex, thrombocytaszám, aszpartát-aminotranszferáz 
(AST)/alanin-aminotranszferáz (ALT) arány, amelyek a parenchymafunkciót vagy a necrosis súlyosságát tükrözik, de közvetve utalnak a stádiumra is.

A direkt és indirekt markerek mérési eredményei kombinálhatók és az így képzett indexek szerepelhetnek a fibrosisdiagnosztikában. Közülük a legegyszerúbb, legolcsóbb és a legjobban validált az aszpartát-aminotranszferáz/thrombocyta hányadosindex (APRI). Szignifikáns fibrosist $(\mathrm{F} \geq 2)$ jelent a $0,5-1,5$ és cirrhosist a $>1,5$ APRIérték [14]. Ma a WHO ezt első vonalú fibrosisszürőnek javasolja a szegény országokban, ahol a tranziens elasztogáfia (TE) nem elérhetô [2].

Leginkább ismert még a Forns-index (thrombocyta, GGT, életkor, koleszterin), a Lok-index (thrombocyta, AST/ALT arány, INR) és a FIB-4 (életkor, AST/thrombocyta hányados, ALT). A szabadalom által védett formulák közül a legjobban validált a Fibrotest ( $\alpha$-2makroglobulin, GGT, apolipoprotein-Al, haptoglobin, szérumbilirubin, életkor és nem), de ilyen még az Enhanced liver fibrosis score (ELF) (életkor, hialuronsav, MMP-3 és TIMP-1), a Hepascore (bilirubin, GGT, hialuronsav, $\alpha$-2-makroglobulin, életkor és nem), valamint a Fibrometer (thrombocytaszám, protrombin, AST, $\alpha$-2-makroglobulin, hialuronsav, karbamid és életkor) [6, $13]$.

A szérumbiomarkerek gyakorlati előnye, hogy hozzáférhetők, elterjedt vizsgálatokon alapulnak, jól reprodukálhatók. Hátrányuk a májspecificitás hiánya, kritikus interpretációt igényelnek, számos komorbid állapot befolyásolja az értékeket. Például álpozitív lehet (a bilirubin miatt) a Fibrotest és a Hepascore Gilbert-kórban vagy hemolízis okozta hyperbilirubinaemiában, de az akut hepatitis is álpozitív eredményt adhat APRI-score, a Forns-index, a FIB-4 vagy a Fibrometer teszt esetén, mivel ezekben a mutatókban az ALT-szint szerepel [13].

\section{A májtömöttség (liver stiffness - LS) mérése}

A tranziens elasztográfiával (TE) már a hazai irodalom is bőven foglalkozott, beleértve saját tapasztalatokat is [8, 9, 10, 11], ezért a technikai részletektől eltekintünk. Röviden: a készülék a májszövetben alacsony frekvenciájú elasztikus hullámokat kelt, és a lökéshullám terjedési sebességét méri. Ez a sebesség annál nagyobb, minél tömöttebb a májszövet, vagyis minél kifejezettebb a fibrosis. A vizsgált májszövet térfogata 100-szorosa a biopsziával nyerhetőnek (a henger $1 \mathrm{~cm}$ széles és $4 \mathrm{~cm}$ hosszú). Maga az eljárás egyszerü, gyors, 5 percet vesz igénybe, ambulanter végezhető, könnyen megtanulható. $\mathrm{Az}$ eredménynek legalább 10 értékelhető mérésen kell alapulnia. A májtömöttség értékét (liver stiffness - LS) kilopascalban kapjuk, az értékek 2,5 kPa és $75 \mathrm{kPa}$ között változnak, a 7,1 és 8,7 kPa közötti LS jelzi a szignifikáns $(\mathrm{F} \geq 2)$ fibrosist, $12,5-14,5 \mathrm{kPa}$ felett a cirrhosist $[15,16]$. Castera szerint a 2,5 és $7,0 \mathrm{kPa}$ közötti LS esetén a fibrosis feltehetően enyhe vagy nincs, $13 \mathrm{kPa}$ felett valószínú a cirrhosis [13].

A TE 85-95\%-os pontossággal mutatja ki a cirrhosist, és $57-90 \%$-os pontossággal a szignifikáns $(\mathrm{F} \geq 2)$ fibrosist. A TE szenzitivitása és specificitása cirrhosisban 0,83 és 0,89 , fibrosisban 0,79 és 0,78 [12]. Papastergiou és $m t-$ sai szerint a TE pontosabb a cirrhosis elörejelzésében, mint a szérummarkerek [17]. A TE az esetek 16-20\%ában nem értékelhető, az LS-eredményt befolyásolja az akut gyulladás, cholestasis, májpangás, étkezés [6, 12].

$\mathrm{Az}$ acoustic radiation force impulse (ARFI) technika előnye, hogy hagyományos ultrahangkészülékhez integrálható. Pontossága megfelel a TE-nek, de szúkebb a mérési tartomány $(0,5-4,4 \mathrm{~m} / \mathrm{s})$, ami korlátozza a cutoff értékek definiálását. Egyébként kisebb volumenú (10 mm hosszú és $6 \mathrm{~mm}$ széles) májszövetet vizsgál, mint a TE, viszont az operátor meg tudja választani a lokalizációt $[13,18]$.

A supersonic shear imaging (SSI) különösen nagy (1 $\mathrm{m} / \mathrm{s}$ ) sebességgel végzi a folyamatos méréseket egy megválasztott terület több pontjáról, így csaknem realtime képet ad a transzducer mozgatása során [19].

A mágneses rezonancia (MR) elasztográfia érzékenyebb, pontosabb a TE-nél, különösen az $\mathrm{F} \geq 2$ stádium meghatározásában. Előnye, hogy az egész májtömeget vizsgálja, hátránya, hogy a vizsgálat drága, nehezen hozzáférhető és időigényes [13, 17, 19, 20].

\section{Kombinációs algoritmusok}

A különböző szérummarkerek, indexek kombinációi növelik a diagnózis pontosságát. Sebastiani és mtsai által kidolgozott úgynevezett SAFE biopsy algoritmus az APRI és a Fibrotest alapján az $\mathrm{F} \geq 2$ fibrosis megítéléséhez szükséges biopsziák számát $50 \%$-kal, a cirrhosisra vonatkozóan 80\%-kal csökkentette [15]. Magunk hasonló algoritmust dolgoztuk ki APRI és FibroScan használatával: 47,8\%-ban lehetett csökkenteni a biopsziaigényt $\mathrm{F} \geq 2$ stádium megítéléséhez [11] (1. ábra).

Castéra és mtsai az úgynevezett bordeaux-i sémában a Fibrotest és FibroScan kombinációt alkalmazták, ez a cirrhosis diagnózisában bizonyult pontosabbnak, mint a SAFE biopsy algoritmus [21].

\section{A nem invazív fibrosismarkerek alkalmazásai a klinikai gyakorlatban}

\section{A májbetegség stádiummeghatározása}

Fontos annak megállapítása, hogy a beteg enyhe vagy előrehaladott májbetegségben szenved-e. A szignifikáns fibrosis $(\mathrm{F} \geq 2)$ azonosítására általában a TE és szérummarkerek egyformán megfelelők. A diagnosztikus érzékenység növelhető, ha két független módszert kombinálnak, például TE-t együtt szérummarker-vizsgálattal [15, 22]. Papastergiou és mtsai szerint a TE akár 90\%- 


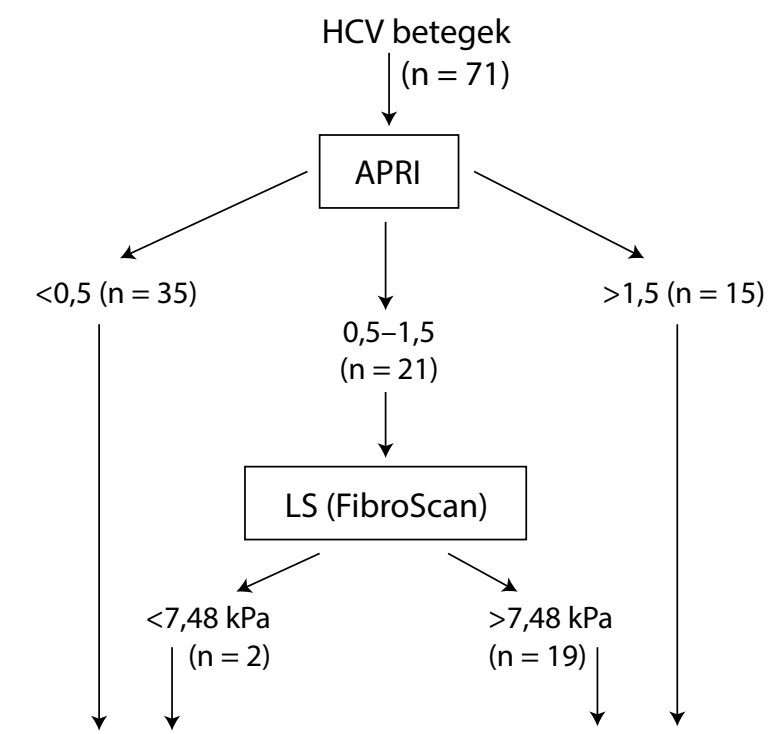

Májbiopszia szükséges a fibrosis megítélésére $(n=37)$
Szignifikáns fibrosis $(\mathrm{F} \geq 2)$ (biopszia nem szükséges) $(n=34)$

1. ábra $\quad$ Algoritmus az APRI és TE kombinálásával a szignifikáns $(\mathrm{F} \geq 2)$ fibrosis megállapítására

APRI $=$ GOT $/$ thrombocyta hányados $; \mathrm{TE}=$ tranziens elasztog ráfia.

0,5 alatti APRI és $7,48 \mathrm{kPa}$ alatti LS esetén nem lehet kizárni a szignifikáns $(\mathrm{F} \geq 2)$ fibrosist, ezért a stádiummeghatározáshoz májbiopszia szükséges.

1,5 feletti APRI és $>7,48 \mathrm{kPa}$ LS egyértelmúen $\mathrm{F} \geq 2$ stádiumra utal, ezért biopszia nem szükséges ennek bizonyítására

ban feleslegessé teheti a biopsziát. Az AST/ALT hányados (AAR), az APRI, a protrombin, a Fibrotest és thrombocytaszám közül a TE a legpontosabb indikátora a korai cirrhosisnak: 12,5 $\mathrm{kPa}$ alatt: 95\%-ban kizárható, felette 85\%-ban valószínúsíthető a diagnózis [17].

\section{Az antivirális kezelés indikálása}

A HCV-RNS, a gyulladásos aktivitás (ALT, hisztológia) és/vagy fibrosis (a TE vagy biomarkerek) együtt jelentik a HCV-infekció antivirális kezelésének indikációját, de májbiopszia szükséges, ha a nem invazív vizsgálatok ellentmondásos eredményt adnak [13]. Jelenleg az általánosan elérhető IFN-alapú kettős vagy a proteázgátlóval kombinált hármas kezelés indokolt HCV-RNS-pozitív betegben gyulladásos aktivitás (kóros GPT vagy szövet$\tan$ ) vagy $\mathrm{F} \geq 2$ fibrosis esetén. Az IFN-mentes, nagy (>90\%-os), tartós virológiai gyógyulási arányt (SVR) eredményező, direkt ható antivirális szerek (DDA) adására még egy ideig csak az elörehaladt, F3-F4 fibrosisos/ cirrhosisos betegek élveznek prioritást $[2,23]$. Mindez tükrözi a fibrosisdiagnosztika jelentőségét a HCV-terápia megválasztásában. Amennyiben minden felnőtt HCV-beteg kapna antivirális kezelést, költséghatékonysági szempontból már nem lenne jelentősége a fibrosisstádiumok megkülönböztetésének [24].

\section{A terápiás válasz monitorozása}

A nem invazív fibrosisdiagnosztika elónye, hogy a vizsgálatok a kórlefolyás alatt ismételhetők, a kezelésre kapott válasz, a fibrosis fokának változása monitorozható. Korábban szignifikáns hisztológiai javulás volt dokumentálható ismételt biopsziákkal virológiailag gyógyult HCV-betegekben, majd hasonló következtetésre jutottak a nem invazív fibrosistesztekkel is.

D'Ambrosio és mtsai peg-IFN plusz RBV (P/R) kezelt HCV-cirrhosisos betegekben a 4 éves követés utáni kontrollbiopsziával az SVR-betegek 61\%-ában igazoltak cirrhosisregressziót, ez a fibrosiskiterjedés és a kollagéntartalom csökkenésével járt [25]. Martinez és mtsai kezelt és nem kezelt HCV-betegekben a májtömöttség (LS) szignifikáns csökkenését csak SVR esetén észlelték, a kezelés előtti magas GPT- és LS-érték, valamint a nonHCVl genotípus független prediktora volt a regressziónak [26]. Poynard és mtsai Fibrotest és TE alkalmazásával ismételten vizsgáltak IFN-alapú kezelésben részesült, elörehaladott fibrosisú HCV-betegeket. SVR esetén 49\%-ban észlelték a fibrosis regresszióját, de 12\%-ban új cirrhosis jelentkezését is regisztrálták, 10 év után mindössze 5\%-ban volt igazolható a cirrhosis regressziója, és 5\% esélye volt a HCC kialakulásának SVR-betegekben is [27]. Fernández-Rodríguez és mtsai szerint P/R kezelt HCV-cirrhosisban 5 éves mortalitás SVR esetén $2 \%$, nem SVR-betegekben $14 \%$ volt [28]. Hézode és mtsai csak az SVR-betegekben észlelték a fibrosis regresszióját. Ha alacsony volt a fibrosisstádium az antivirális kezelés esetén, nagyobb volt a tartós virológiai válasz (SVR) aránya [29]. Ezekkel az eredményekkel megegyeznek saját megfigyeléseink is [30] (2. ábra).

\section{A prognózis megítélése nem invazív módszerekkel}

Vergniol és mtsai a TE, a Fibrotest, az APRI és FIB-4 összehasonlító vizsgálata alapján azt állapították meg, hogy a TE-nek és a Fibrotestnek volt a legnagyobb prediktív értéke a krónikus $\mathrm{C}$-vírus hepatitis 5 éves kimenetele szempontjából. Az LS prognosztikai tényezőnek bizonyult HCV-cirrhosisban: az LS korrelált a portalis hypertensióval a hepaticus vénásnyomás-gradiens (HVPG) alapján [31]. Castéra és mtsai szerint az LS-nek $12,5 \mathrm{kPa}$ határt tekintve 95\%-os a negatív prediktív értéke (NPV) cirrhosisra vonatkozóan, a 21,5 kPa feletti LSérték a varix jelenlétére utal, míg a $30,5 \mathrm{kPa}$ a nagy varixok prediktora [32].

Kazemi és mtsai vetették fel először, hogy az LS prediktora lehet a súlyos nyelőcső-varicositasnak cirrhosisban: anyagukban a $19 \mathrm{kPa}$ LS érzékenysége $84 \%$, pozitív prediktív értéke (PPV) 47\%, negatív prediktív értéke (NPV) $93 \%$ volt a $\geq$ PII varixra vonatkozóan [33]. Bosch kommentárjában ezeket az adatokat előzetesnek tartotta, és további vizsgálatokkal való megerősítésüket javasolta. Ugyanakkor elismerte, hogy az LS jelzője lehet 

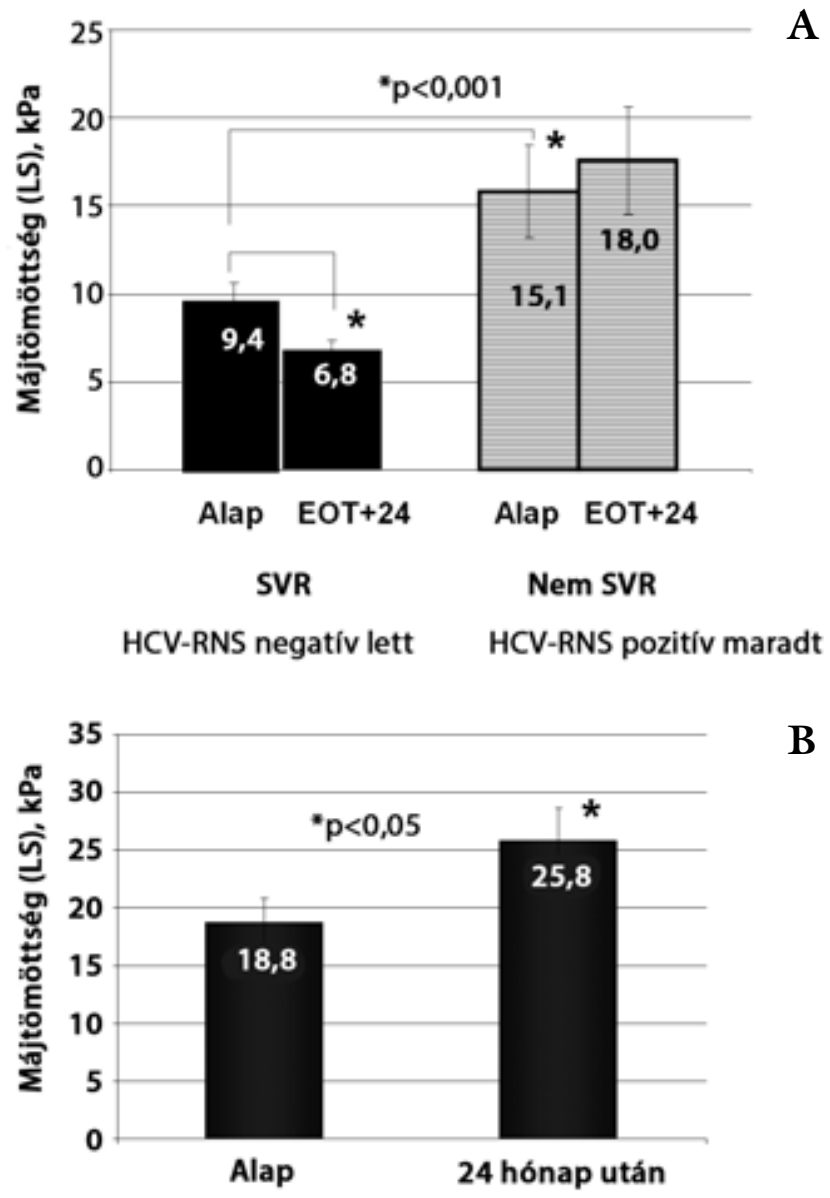

2. ábra $\quad$ A TE-mért májtömöttség (LS) és a tartós virológiai válasz (SVR) krónikus C hepatitis antivirális terápiája kapcsán

A) Az LS csökkent a virológiailag gyógyulókban (SVR) és nőtt a nem reagálókban 6 hónappal $(\mathrm{EOT}+24)$ a kezelés befejezése után.

B) A nem kezelt HCV-betegekben 24 hónap alatt nőtt az LS érték

cirrhosisban a progressziónak, ha a varix megítélésében nem is jobb, mint a thrombocyta/lépnagyság hányadosindex [34].

A cirrhosis és a következményes nyelőcső-varicositas nem invazív eljárásokkal történó előrejelzése terén korábban elsőként a thrombocytaszám vetődött fel. Garcia-Tsao és mtsai már 1997-ben utaltak a thrombocytopenia diagnosztikus szerepére portalis hypertensióban a varixpredikciót illetően [35]. Később számosan definiálták az alacsony thrombocytaszámot, mint a cirrhosis és nyelöcső-varicositas prediktorát. Az értékek 68000 160000 között mozogtak, és egyre több olyan indexet írtak le, amelyekben a thrombocytaszám mellett például az életkor, a nem, a szérumbilirubin, az alfa-2-makroglobulin, az ALT/AST hányados, a protrombin, a koleszterin és a GGT szerepelt [10].

Giannini és mtsai a thrombocytaszám/lépátmérő hányadost (PSR) javasolták cirrhosisban a nyelöcső-varicositas prediktoraként, a <909 index negatív prediktív értéke 100\%-nak bizonyult, bár későbbi vizsgálataik ennél kisebb értéket igazoltak [36]. Sebastiani és mtsai két komplex nem invazív fibrosismutató (a Lok- és a Fornsindex) összevonásával (a thrombocytaszám, protrombin, GOT, GPT, GGT, életkor és koleszterinérték alapján) 90\%-os negatív prediktív értékkel kizárták a klinikailag releváns varix (nagy varix vagy kis varix piros folttal és Child C cirrhosissal) jelenlétét. Ennek alapján az endoszkópiát az esetek egyharmadában mellózhetőnek tartották. (A PPV értéke varix jelenlétére vonatkozóan 88\% volt.) Az említett markereket hasznosnak ítélték, mint első vonalú szứrővizsgálatokat cirrhosisban a súlyos varicositas előrejelzésében [37].

Ilyen irányú saját vizsgálatainkban azt állapítottuk meg, hogy a TE nemcsak az előrehaladott fibrosis kizárásában, illetve annak megerősítésében, hanem a varixvérzés kockázatának előrejelzésében is szerepet kaphat [10]. A TE mind a nyelöcső-varicositas jelenlétének, mind pedig a vérzésveszéllyel járó $\geq$ PII súlyosságú varicositasnak az előrejelzésére alkalmas nem invazív eljárásnak bizonyult. A 19,2 kPa alatti LS mellett alacsony volt a varixvérzés kockázata, 19,2 kPa feletti LS (elörehaladott cirrhosis gyanúja!) esetén már szükséges az oesophagogastro-bulboszkópia a varixok megítélésére (3. ábra).

Az LS ismételt meghatározása az idült májbetegség kórlefolyása alatt prediktora lehet a progressziónak, a vérzésveszéllyel járó, nagy nyelőcső-varicositas kialakulásának [10].

Bár a TE utalhat a klinikailag szignifikáns portalis hypertensióra ( $\geq 10 \mathrm{Hgmm})$ és a nagy varix jelenlétére, nem helyettesítheti sem a HVPG-mérést, sem az endoszkópiát. Nemcsak a varixnagyság, de a cseresznyepiros foltok is fontosak a vérzésveszély megítéléséhez, ez pedig csak az endoszkópiával lehetséges. A cirrhosis diagnózisa idején javasolt endoszkópia igénye ezért nem vitatható. Ugyanakkor a kórlefolyás alatti endoszkópos követés gyakoriságát a TE saját adataink szerint 36\%-kal, Kazemi és mtsai szerint 43\%-kal csökkentheti [33].

Galvin és mtsai az LS-t cirrhosisban a minimális hepaticus encephalopathia (mHE) prediktoraként is tanulmányozták. E tekintetben a 20,9 kPa LS-határérték érzékenysége $73 \%$, specificitása $63 \%$ volt, ezért $20,9 \mathrm{kPa}$ LS felett a betegek további kivizsgálását javasolták mHE irányába [38].

Az LS-vizsgálathoz hasonlóan a léptömöttség (spleen stiffness - SS) TE-vel való mérését is alkalmazták a nyelőcső-varicositas előrejelzésében: Calvaruso és mtsai szerint a módszer 80\%-os szenzitivitással és 70\%-os specificitással volt prediktora a nagy varixnak, hasonlóképpen, mint a thrombocyta/lép hányados (PSR) a varix jelenlétére vonatkozóan (érzékenység: 75\%, specificitás: 71\%) [39]. Colecchia és mtsai HCV-cirrhosisos betegekben az LS és az SS meghatározása mellett vizsgálták a hepaticus vénásnyomás-gradienst (HVPG), a májtömöttség-lépátmérö/thrombocyta hányadost (LSPR), valamint a thrombocytaszám/lépátmérő hányadost (PSR). Az LS és az SS pontosabb nem invazív mutatója volt a portalis hypertensiónak és a varix jelenlétének, mint a többi paraméter. A 41,3 kPa SS 98\%-os érzékenységgel és 66\%-os specificitással kizárta a nagy varix jelenlétét [40]. 

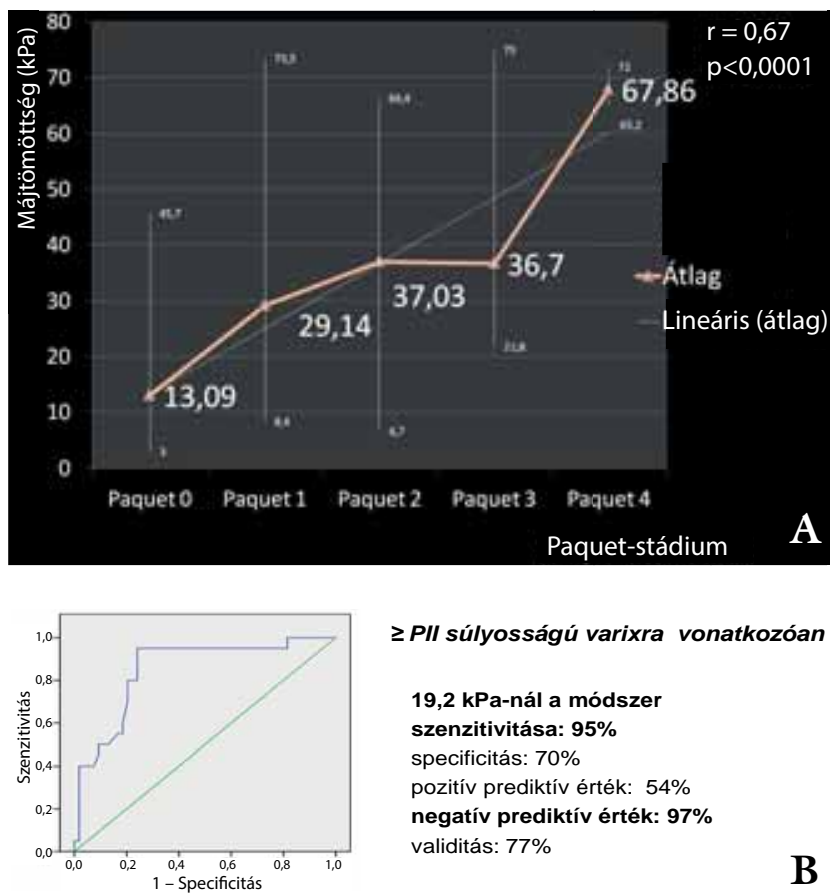

B

A TE-vel megállapított májtömöttség (LS) és az endoszkópiával igazolt nyelőssővvarix-stádiumok kapcsolata

A) Az LS-értékek és a varix-Paquet-stádiumok összefüggése. B) A 19,2 kPa LS nagy érzékenységgel utal $\geq$ PII varixra, és magas a negatív prediktív értéke (NPV)

Berzigotti és mtsai nyelőcső-varicositas irányában endoszkópián átesett cirrhosisos betegekben a szignifikáns portalis hypertensiót $(\mathrm{CSPH})(>10 \mathrm{Hgmm})$ a HVPG mérésével állapították meg, a lépátmérốt ultrahanggal, a májtömöttséget (LS) TE-vel vizsgálták. A legjobb nem invazív mutatónak az LS bizonyult a CSPH-s betegek azonosításában. Ha a TE-t kombinálták a thrombocytaszámmal és a lépmérettel, az érzékenység 90,9\%-ra nőtt, 85\%-ban azonosítani lehetett a varixos betegeket [41].

A HCV-cirrhosis legsúlyosabb szövődménye a hepatocellularis carcinoma (HCC). HCC esetén korai, még tünetmentes szakban való diagnózis ad esélyt a kuratív kezelésre, ami 15-20\%-ban lehetséges. A cirrhosisos betegek 6 havonta történő ultrahangszúrése ezt a korai felismerést szolgálja $[2,23]$.

TE-vizsgálatok HCC-betegekben a cirrhosisos átlag 27 kPa LS-értékhez képest különösen magas (átlag 42 $\mathrm{kPa}$ ) májtömöttséget jeleztek [42]. Mások a HCC-góc felett átlag 72,5 kPa LS-t detektáltak [43]. Feier és mtsai regressziós modellje alapján a magas LS, az interquartile range (IQR), az emelkedett ALT- és az AFP-érték kombinációja a HCC nagy pontosságú nem invazív prediktorának bizonyult [42].

\section{Következtetések}

A HCV-infekció globális endémiája okozta morbiditás és mortalitás csökkentése csak a nagyszámú HCV-fertőzött

egyén megtalálása és hatékony antivirális kezelése révén várható. Ennek a folyamatnak az első lépése a kockázati populációk széles körú szürése, beleértve a stádium meghatározását is. A fibrosisdiagnosztika nem invazív módszerei különösen kombinációkban alkalmazva hatékonyak, széles körben elérhetók, bár költségük változó. A szérumbiomarkerek és különösen a TE nemcsak a szúrésben, a kezelés indikációjában (és a prioritás eldöntésében), hanem a terápiás válasz monitorozásában, így például a fibrosisregresszió kimutatásában, valamint a prognózis megítélésében is szerepet játszhatnak. A krónikus májbetegségek kórismézésének és differenciáldiagnosztikájának a májbiopszia ma is integráns része, a stádium megállapításában és a követésben azonban a nem invazív fibrosismutatók hasznos kiegészítők, amelyek révén csökkenthető a szükséges májbiopsziák száma.

Anyagi támogatás: A dolgozat az OTKA (K81514) támogatásával készült.

Szerzői munkamegosztás: P. A.: A dolgozat végső megfogalmazása. V. Á.: Vizsgálatok kivitelezése. P. G.: Vizsgálatok megtervezése és kivitelezése. A kézirat végleges változatát mindhárom szerző elolvasta és jóváhagyta.

Érdekeltségek: P. A. és P. G. előadói/tanácsadói díjban és/vagy kutatási támogatásban részesült az alábbi gyógyszer elóállítóktól/forgalmazóktól: AbbVie Kft., Janssen Cilag Kft., Roche Magyarország Kft.

\section{Irodalom}

[1] Lavanchy, D.: Evolving epidemiology of hepatitis C virus. Clin. Microbiol. Infect., 2011, 17(2), 107-115.

[2] World Health Organization: Guidelines for the screening, care and treatment of persons with hepatitis C infection. April 2014, pp. 1-122.

[3] Infections. CotPaCoVH. Hepatitis and liver cancer: A National Strategy for Prevention and Control of Hepatitis B and C. In: Colvin, H. M., Mitchell, A. E. (eds.): Hepatitis and liver cancer: A National Strategy for Prevention and Control of Hepatitis B and C. Institute of Medicine of the National Academies, Washington, 2010.

[4] Smith, B. D., Morgan, R. L., Beckett, G. A., et al.: Recommendations for the identification of chronic hepatitis $C$ virus infection among persons born during 1945-1965. MMWR Recomm. Rep., 2012, 61(RR-4), 1-32.

[5] Coffin, P. O., Scott, J. D., Golden, M. R., et al.: Cost-effectiveness and population outcomes of general population screening for hepatitis C. Clin. Infect. Dis., 2012, 54(9), 1259-1271.

[6] Sebastiani, G., Gkouvatsos, K., Pantopoulos, K.: Chronic hepatitis C and liver fibrosis. World J. Gastroenterol., 2014, 20(32), 11033-11053.

[7] Yano, M., Kumada, H., Kage, M., et al.: The long-term pathological evolution of chronic hepatitis C. Hepatology, 1996, 23(6), 1334-1340.

[8] Pár, A., Pár, G.: Non-invasive fibrosis assessment in chronic hepatitis $\mathrm{C}$ : aspartate-aminotransferase to platelet ratio index (APRI) and transient elastography (FibroScan). [Nem invazív fibrosisdiagnosztika krónikus C-hepatitisben: aszpartát-aminotranszferáz/thrombocyta hányadosindex (APRI) és tranziens elasztográ- 
fia (FibroScan).] Orv. Hetil., 2010, 151(47), 1951-1955. [Hungarian]

[9] Horváth, G.: New non-invasive tool for assessment of liver fibrosis: transient elastography. [A májfibrosis meghatározásának új, noninvazív módszere: tranziens elasztográfia (FibroScan).] Orv. Hetil., 2011, 152(22), 860-865. [Hungarian]

[10] Pár, G., Trosits, A., Pakodi, F., et al.: Liver stiffness measurement selects patients with chronic liver diseases at risk of bearing large oesophageal varices. Z. Gastroenterol., 2013, 51(5), A52 (Abstract).

[11] Pár, G., Vincze, Á., Berki, T., et al.: Serum fibrosis markers (procollagen-III-peptide, hyaluronic acid, transforming growth factor beta-1), aspartate-aminotransferase to platelet ratio index (APRI), and transient elastography (FibroScan) in patients with chronic HCV infection. Clin. Exp. Med. J., 2011, 5(2-3), 101-118.

[12] Schaff, Z.: The value of liver biopsy in chronic hepatitis. [A májbiopszia értéke krónikus hepatitisben.] Orv. Hetil., 2011, 52(22), 856-858. [Hungarian]

[13] Castera, L.: Noninvasive methods to assess liver disease in patients with hepatitis B or C. Gastroenterology, 2012, 142(6), 1293-1302.e4.

[14] Wai, C. T., Greenson, J. K., Fontana, R. J.: A simple non-invasive index can predict both significant fibrosis and cirrhosis in patients with chronic hepatitis C. Hepatology, 2003, 38(2), 518526.

[15] Sebastiani, G., Halfon, P., Castera, L., et al.: SAFE biopsy: a validated method for large-scale staging of liver fibrosis in chronic hepatitis C. Hepatology, 2009, 49(6), 1821-1827.

[16] Armstrong, M. J., Corbett, C., Hodson, J., et al.: Operator training requirements and diagnostic accuracy of Fibroscan in routine clinical practice. Postgrad. Med. J., 2013, 89(1058), 685-692.

[17] Papastergiou, V., Tsochatzis, E., Burroughs, A. K.: Non-invasive assessment of liver fibrosis. Ann. Gastroenterol., 2012, 25(3), 218-231.

[18] Friedrich-Rust, M., Nierhoff, J., Lupsor, M., et al.: Performance of acoustic radiation force impulse imaging for the saging of liver fibrosis: a pooled meta-analysis. J. Viral. Hepat., 2011, 19(2), e212-e219.

[19] Sporea, I., Bota, S., Jurchis, A., et al.: Acoustic radiation force impulse and supersonic shear imaging versus transient elastography for liver fibrosis assessment. Ultrasound Med. Biol., 2013, 39(11), 1933-1941.

[20] Huwart, L., Sempoux, C., Vicaut, E., et al.: Magnetic resonance elastography for the noninvasive staging of liver fibrosis. Gastroenterology, 2008, 135(1), 32-40.

[21] Castéra, L., Sebastiani, G., Le Bail, B., et al.: Prospective comparison of two algorithms combining non-invasive methods for staging liver fibrosis in chronic hepatitis C. J. Hepatol., 2010, 52(2), 191-198.

[22] Boursier, J., de Ledinghen, V., Zarski, J. P., et al.: Comparison of eight diagnostic algorithms for liver fibrosis in hepatitis C: new algorithms are more precise and entirelly noninvasive. Hepatology, 2012, 55(1), 58-67.

[23] European Association for the Study of the Liver: EASL Clinical Practice Guidelines: management of hepatitis $\mathrm{C}$ virus infection. J. Hepatol., 2014, 60(2), 392-420.

[24] Tsochatzis, E., A., Crossan, C., Longworth, L., et al.: Cost-effectiveness of noninvasive liver fibrosis tests for treatment decisions in patients with chronic hepatitis C. Hepatology, 2014, 60(3), 832-843.

[25] D’Ambrosio, R., Aghemo, A., Rumi, M. G., et al.: A morphometric and immunohistochemical study to assess the benefit of a sustained virological response in hepatitis $\mathrm{C}$ virus patients with cirrhosis. Hepatology, 2012, 56(2), 532-543.

[26] Martinez, S. M, Foucher, J., Combis, J. M., et al.: Longitudinal liver stiffness assessment in patients with chronic hepatitis $\mathrm{C}$ undergoing antiviral therapy. PLoS ONE, 2012, 7(10), e47715. doi:10.1371/journal.pone.0047715.
[27] Poynard, T., Moussali, J., Munteanu, M., et al.: Slow regression of liver fibrosis presumed by repeated biomarkers after virological cure in patients with chronic hepatitis C. J. Hepatol., 2013, $59(4), 675-683$.

[28] Fernández-Rodríguez, C. M., Alonso, S., Martinez, S. M., et al., Group for the Assessment of Prevention of Cirrhosis Complication and Virological Response (APREVIR): Peginterferon plus ribavirin and sustained virological response in HCV-related cirrhosis: Outcomes and factors predicting response. Am. J. Gastroenterol., 2010, 105(10), 2164-2173.

[29] Hézode, C., Castéra, L., Roudot-Thoraval, F., et al.: Liver stiffness diminishes with antiviral response in chronic hepatitis C. Aliment. Pharmacol. Ther., 2011, 34(6), 656-663.

[30] Pár, G., Szinku, Z., Haragh, A., et al.: Sustained virologic response to antiviral therapy for chronic hepatitis $\mathrm{C}$ vírus infection is associated with regression of liver fibrosis assessed by transient elastography. Z. Gastoenterol., 2014, 52, A50. DOI: 10. 1055/ s-0034-1376110.

[31] Vergniol, J., Foucher, J., Terrebonne, E., et al.: Noninvasive tests for fibrosis and liver stiffness predict 5-year outcomes of patients with chronic hepatitis C. Gastroenterology, 2011, 140(7), 19701979, 1979.el-e3.

[32] Castéra, L., Pinzani, M., Bosch, J.: Non invasive evaluation of portal hypertension using transient elastography. J. Hepatol., 2012, 56(3), 696-703.

[33] Kazemi, F., Kettaneh, A., N'kontchou, G., et al.: Liver stiffness measurement selects patients with cirrhosis at risk of bearing large oesophageal varices. J. Hepatol., 2006, 45(2), 230-235.

[34] Bosch, J.: Predictions from a hard liver. J. Hepatol., 2006, 45(2), 174-177.

[35] Garcia-Tsao, G., Escorsell, A., Zakko, M.: Predicting the presence of significant portal hypertenison and oesophageal varices in compensated cirrhotic patients. Hepatology, 1997, 26, 360A (Abstract).

[36] Giannini, E. G., Zaman, A., Kreil, A., et al.: Platelet count/ spleen diameter ratio for the noninvasive diagnosis of esophageal varices: results of a multicenter, prospective validation study. Am. J. Gastroenterol., 2006, 101(11), 2511-2519.

[37] Sebastiani, G., Tempesta, D., Fattovich, G., et al.: Prediction of oesophageal varices in hepatic cirrhosis by simple non-invasive markers: results of a multicenter, large-scale study. J. Hepatol., 2010, 53(4), 630-638.

[38] Galvin, Z., O'Nill, M. T., Lowry, D., et al.: Transient elastography is a useful clinical tool to predict the presence of minimal hepatic encephalopathy in a cohort of compensated cirrhotic patients. Falk Symposium 191, London, Oct. 4-7, 2013.

[39] Calvaruso, V., Di Marco, V., Bronte, F., et al.: High spleen stiffness is related to presence of esophageal varices in patients with HCV cirrhosis. J. Hepatol., 2012, 56(Suppl. 2), S409.

[40] Colecchia, A., Montrone, L., Scaioli, E., et al.: Measurement of spleen stiffness to evaluate portal hypertension and the presence of esophageal varices in patients with HCV-related cirrhosis. Gastroenterology, 2012, 143(3), 646-654.

[41] Berzigotti, A., Seijo, S., Arena, U., et al.: Elastography, spleen size and platelet count identify portal hypertension in patients with compensated cirrhosis. Gastroenterology, 2013, 144(1), 10211l.el.

[42] Feier, D., Lupsor Platon, M., Stefanescu, H., et al.: Transient elastography for the detection of hepatocellular carcinoma in viral C liver cirrhosis. Is there something else than increased liver stiffness? J. Gastrointest. Liver Dis., 2013, 22(3), 283-289.

[43] Yousef, M., Elsharkawy, A., El Beshlawy, M., et al.: Use of ultrasonic transient elastography (Fibroscan) in the assessment of hepatic focal lesion stiffness. Open J. Gastroenterol., 2013, 3(2), $107-112$

(Pár Alajos dr., Pécs, Ifjúság u. 13., 7624 e-mail: par.alajos@pte.hu) 